\title{
Syndrome of Inappropriate Antidiuretic Hormone Secretion in a Patient with Uncontrolled Tyrosinaemia Type 1
}

Abdulhamid Al-Hinai, ${ }^{1}$ Fathiya Al-Murshedi, ${ }^{1}$ Dana Al-Nabhani, ${ }^{2}$ Khalid Al-Thihli ${ }^{1}$

ABSTRACT: Syndrome of inappropriate antidiuretic hormone (SIADH) secretion is a recognisable complication of acute porphyria. We report a nine-year-old female patient with hereditary tyrosinaemia type 1 and poor adherence to nitisinone therapy who presented with acute abdominal pain, vomiting and lethargy at Sultan Qaboos University Hospital, Muscat, Oman in 2016. She subsequently developed generalised tonic-clonic seizures attributable to severe hyponatremia that met the diagnostic criteria of SIADH. The acute porphyria screen also appeared positive. The patient responded well to fluid restriction and was discharged home without immediate neurological sequelae. Although acute porphyria is also a recognised complication of uncontrolled tyrosinaemia type 1 , to the best of the authors' knowledge, no patient with tyrosinaemia type 1 has been reported to present with SIADH.

Keywords: Tyrosinemia Type 1; Hyponatremia; Inappropriate ADH Syndrome; Case Report; Oman.

$\mathrm{H}$ EREDITARY TYROSINAEMIA TYPE 1 (HT-1) is a rare inborn error of the tyrosine metabolism caused by deficiency of the fumarylacetoacetate (FAA) hydrolase enzyme in the tyrosine catabolic pathway. The clinical phenotype has been attributed to succinylacetone (SA). The accumulation of toxic metabolites and their derivatives such as FAA, maleylacetoacetate, succinyl acetoacetate and succinyl acetone causes the hepatic, renal and neurological complications of HT-1., ${ }^{1,2}$ Uncontrolled tyrosinaemia can lead to hepatic cirrhosis that can further progress to hepatocellular carcinoma. Moreover, patients with this diagnosis are also at risk of renal tubular acidosis and progressive renal failure. ${ }^{2}$ Furthermore, the inhibition of delta-5 aminolevulinic acid dehydratase (ALAD) by SA in the heme biosynthetic pathway leads to acute porphyria, a wellknown complication of HT-1, and the patient typically presents with pain crisis associated with autonomic instability. ${ }^{2,3}$

Syndrome of inappropriate antidiuretic hormone (SIADH) is defined by the unsuppressed release of antidiuretic hormone (ADH) from the pituitary gland or non-pituitary sources that result in impaired water excretion leading to hyponatraemia with hypervolaemia or euvolaemia. ${ }^{4}$ Hyponatraemia, secondary to $\mathrm{SIADH}$, is a common electrolyte disturbance occurring in approximately $30 \%$ of hospitalised patients. The diagnosis of SIADH is based on the classic Schwartz and Bartter criteria that were described in 1967.,5 SIADH is most commonly due to secondary systemic causes that are highly heterogeneous. Among the aetiologies leading to SIADH is porphyria, a well- known complication in patients with uncontrolled tyrosinaemia type 1.7

Although SIADH is a well reported complication of porphyria, it is rarely reported as a complication in a patient with HT-1. This case report describes a nine-year-old female patient, diagnosed at a very young age with HT-1. The patient presented with acute porphyria-like crisis and severe symptomatic hyponatraemia fulfilling the diagnostic criteria of SIADH.

\section{Case Report}

We report a nine-year-old female patient born to consanguineous parents presenting to Sultan Qaboos University Hospital (SQUH), Muscat, Oman, in 2016. She had two older siblings diagnosed with tyrosinaemia type 1. Following genetic testing for the known familial mutation c.785G>A (p.Trp262*) in the FAH gene, she was confirmed to have tyrosinaemia type 1 since the age of one month. The patient was reasonably controlled on nitisinone (also known as 2-[2-nitro4-trifluoromethylbenzoyl]-1,3-cyclohexanedione) therapy given at a dose of $1 \mathrm{mg} / \mathrm{kg} /$ day in combination with protein restriction. However, the patient's adherence to therapy started to decline after the age of six years. She started showing measurable succinylacetone in the urine, although it had initially disappeared following initiation of nitisinone therapy.

The patient recently presented to a local healthcare centre with a history of abdominal pain, vomiting, lethargy and undocumented fever for three days. On 
physical examination, she was conscious, alert and her vital signs were within the normal range. Her weight on admission was $21 \mathrm{~kg}$. The patient was noted to be clinically dehydrated and have generalised abdominal tenderness. Initial laboratory investigations showed urine ketones at $4+$ and normal sodium $(142 \mathrm{mEq} / \mathrm{L}$; $\left.\mathrm{Na}^{+}\right)$, potassium $\left(4.7 \mathrm{mEq} / \mathrm{L} ; \mathrm{K}^{+}\right)$and bicarbonate $(18$ $\mathrm{mmol} / \mathrm{L} ; \mathrm{HCO}_{3}{ }^{-}$) levels, with pre-renal azotaemia, urea of $17.6 \mathrm{mmol} / \mathrm{L}$ and high creatinine of $114 \mu \mathrm{mol} / \mathrm{L}$.

The patient was subsequently admitted with the clinical impression of acute gastroenteritis with clinical dehydration. She was given two boluses of normal saline (NS), each at a dose of $20 \mathrm{~mL} / \mathrm{kg} /$ dose. She was also put on dextrose $10 \%$ with $0.9 \%$ sodium chloride solution (D10\%NS) at a one and a half maintenance rate $(90 \mathrm{~mL} /$ hour$)$. This fluid management continued for approximately 40 hours. After 34 hours of initiating management, the patient developed tonicclonic seizure (TCS) with up-rolling of the eyes. The episode lasted for a minute and a half and was aborted using diazepam $(0.2 \mathrm{mg} / \mathrm{kg})$. Laboratory investigations showed a sodium concentration of 113 $\mathrm{mEq} / \mathrm{L}$, chloride concentration of $76 \mathrm{mmol} / \mathrm{L}$, normal creatinine of $39 \mu \mathrm{mol} / \mathrm{L}$, with normalised urea of 2.4 $\mathrm{mmol} / \mathrm{L}$, magnesium of $0.4 \mathrm{mmol} / \mathrm{L}$ and phosphate of $0.79 \mathrm{mmol} / \mathrm{L}$. The patient had hypoalbuminaemia with normal albumin-corrected calcium.

When the patient was transferred to SQUH, her Glasgow coma scale (GCS) score dropped from 15 to 11 out of 15 and her pupils were dilated at 4-5 mm. Her blood pressure was normal for her age and weight
(127/94 mmHg) and other vital signs were within the normal range. The patient was well hydrated receiving intravenous D10\%NS at a rate of $90 \mathrm{~mL} /$ hour. Eight hours after admission, the patient developed another episode of TCS which lasted less than a minute and was self-aborted. Repeated laboratory investigations showed $\mathrm{Na}^{+}$of $114 \mathrm{mEq} / \mathrm{L}$ and very low serum osmolality of $236 \mathrm{mOsmol} / \mathrm{kg}$. The cortisol level was $488 \mathrm{nmol} / \mathrm{L}$ (normal range: $185-624 \mathrm{nmol} / \mathrm{L}$ ). Thyroid function tests, albumin and transaminases were all within the normal range.

Given the absence of clinical signs of fluid overload and with the patient being euvolaemic, this severe symptomatic hyponatraemia with euvolaemia was most likely due to SIADH. The patient was given two boluses of $3 \%$ sodium chloride solution $(50 \mathrm{~mL} /$ hour) following which the total fluid rate (TFR) was reduced to $20 \mathrm{~mL} /$ hour of D10\%NS for a rate of 1 $\mathrm{mL} / \mathrm{kg} /$ hour. The osmolality and $\mathrm{Na}^{+}$concentration improved with fluid restriction [Figure 1]. Following fluid restriction, the patient developed polyuria and was managed with adjustment of the fluid rate. The plasma amino acid profile showed elevation of tyrosine at $319.8 \mu \mathrm{mol} / \mathrm{L}$ (normal range: 25-115 $\mu \mathrm{mol} / \mathrm{L}$ ). The succinylacetone assay was not done. The urine porphyria screen was positive with random porphyrin at $427 \mathrm{nmol} / \mathrm{L}$ and a urine porphyrin to creatinine ratio of $178 \mathrm{nmol} / \mu \mathrm{mol}$ (normal range: $<35 \mathrm{nmol} /$ $\mu \mathrm{mol})$ with detectable random porphobilinogen. The patient's symptoms subsequently improved, sodium concentration normalised, and she was discharged

Table 1: Biochemical profile and fluid management of a nine-year-old patient with hereditary tyrosinaemia type 1 over five days of admission

\begin{tabular}{|c|c|c|c|c|c|c|c|}
\hline & $\begin{array}{c}\text { At } \\
\text { admission }\end{array}$ & $\begin{array}{l}\text { After } 8 \\
\text { hours }^{*}\end{array}$ & $\begin{array}{l}\text { After } 12 \\
\text { hours }\end{array}$ & $\begin{array}{l}\text { After } 16 \\
\text { hours }\end{array}$ & $\begin{array}{l}\text { After } 24 \\
\text { hours }\end{array}$ & $\begin{array}{l}\text { After three } \\
\text { days }\end{array}$ & $\begin{array}{c}\text { At } \\
\text { discharge }\end{array}$ \\
\hline $\begin{array}{l}\text { Serum } \\
\text { osmolality in } \\
\mathrm{mOsmol} / \mathrm{kg}\end{array}$ & - & 236 & 239 & 246 & 267 & 275 & 283 \\
\hline $\begin{array}{l}\mathrm{Na}^{+} \text {in } \\
\mathrm{mEq} / \mathrm{L}\end{array}$ & 113 & 114 & 116 & 128 & 131 & 133 & 137 \\
\hline $\begin{array}{l}\text { Urine } \mathrm{Na}^{+} \text {in } \\
\mathrm{mmol} / \mathrm{L}\end{array}$ & - & - & - & 101 & - & - & - \\
\hline $\begin{array}{l}\text { Urine } \\
\text { osmolality in } \\
\mathrm{mOsmol} / \mathrm{kg}\end{array}$ & - & - & - & 284 & - & - & 213 \\
\hline $\begin{array}{l}\text { Rate of IV } \\
\text { fluid }^{\ddagger}\end{array}$ & $\begin{array}{l}\text { TFR 150\%, } \\
90 \mathrm{~mL} / \text { hour }\end{array}$ & $\begin{array}{l}\text { Two bolus } \\
50 \mathrm{~mL} \text { each }\end{array}$ & $\begin{array}{l}\text { TFR to } 50 \% \text {, } \\
50 \mathrm{~mL} / \text { hour }\end{array}$ & $\begin{array}{l}\text { TFR to } 30 \% \text {, } \\
20 \mathrm{~mL} / \text { hour }\end{array}$ & $\begin{array}{l}\text { TFR as } 80 \% \text {, } \\
50 \mathrm{~mL} / \text { hour }\end{array}$ & $\begin{array}{l}\text { TFR as } 80 \% \text {, } \\
50 \mathrm{~mL} / \text { hour }\end{array}$ & TFR as $100 \%$ \\
\hline Urine output & - & $\begin{array}{c}2.6 \mathrm{~mL} / \mathrm{kg} / \\
\text { hour }\end{array}$ & - & $\begin{array}{c}6.4 \mathrm{~mL} / \mathrm{kg} / \\
\text { hour }\end{array}$ & $\begin{array}{c}5.5 \mathrm{~mL} / \mathrm{kg} / \\
\text { hour }\end{array}$ & $\begin{array}{c}1.5 \mathrm{~mL} / \mathrm{kg} / \\
\text { hour }\end{array}$ & - \\
\hline
\end{tabular}

$\mathrm{Na}+=$ sodium; $\mathrm{D} 10 \%$ = dextrose $10 \% ; \mathrm{NS}=$ normal saline $(0.9 \% \mathrm{NaCl}) ; \mathrm{IV}=$ intravenous; $T F R=$ total fluid rate

"Second tonic-clonic seizure occure. ${ }^{\dagger} 30 \mathrm{~mL}$ from D10\%NS and $20 \mathrm{~mL}(1 \mathrm{~mL} / \mathrm{kg} /$ hour $)$ of $3 \% \mathrm{NaCl} .{ }^{\neq}$Calculated only for the D10\%NS (patient's weight was $20 \mathrm{~kg}$ ). 


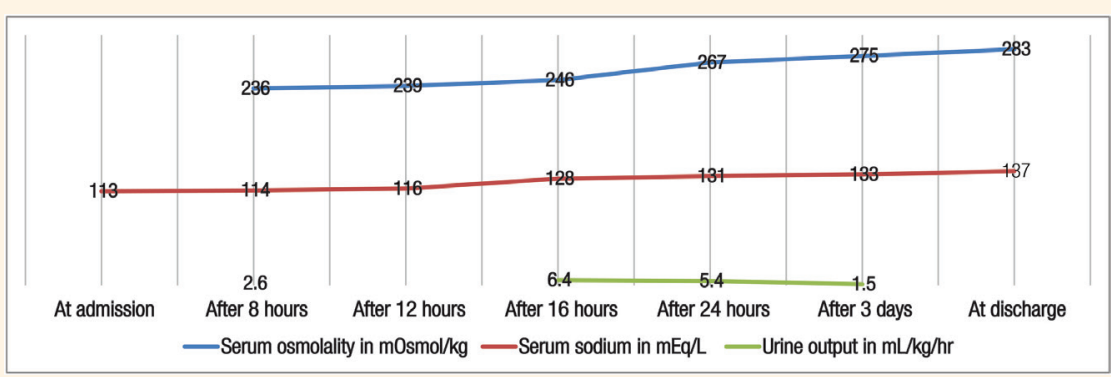

Figure 1: The course of sodium, serum osmolality and urine output during admission of a nine-year-old female patient with hereditary tyrosinaemia type 1 .

after five days. Over the past four years, the patient had not experienced a recurrence of seizures and hyponatraemia when adherent to therapy. However, her adherence with therapy was still suboptimum following discharge and she was admitted with another episode of symptomatic hyponatraemia a few months later. Informed consent was obtained from the patient's uncle (legal guardian) for the purpose of publication.

\section{Discussion}

The neurogenic crisis in HT-1 has a wide spectrum of symptoms that include irritability, lethargy and pain crisis that may progress to cause autonomic instability (hyponatraemia and hypertension) and a Guillain-Barré syndrome-like presentation. ${ }^{9}$ The pathophysiology of the crisis was attributed to the direct toxic effect of delta 5-aminolevulinic acid and SA on the central nervous system. ${ }^{9}$ Although SIADH is a well-reported complication of the acute porphyria crisis, it is not known why only a fraction of patients with acute porphyria crisis develop SIADH. ${ }^{8}$ This may in part reflect the limited understanding of the pathogenesis behind SIADH in porphyria crisis, its multifactorial nature or the fact that it may truly be under-reported. ${ }^{10}$

Questions have also been raised about whether some patients with acute intermittent porphyria were truly euvolaemic. ${ }^{11}$ The pathophysiology of hyponatraemia in acute porphyria, despite being frequently reported in as many as $40 \%$ of cases, is still not very well understood. ${ }^{12}$ While it has been attributed in some reports to the syndrome of inappropriate antidiuresis, there may also be elements of renal or gastrointestinal sodium loss. ${ }^{13}$

Despite the number of patients with tyrosinaemia known worldwide and the likelihood of the existence of non-adherent older patients with complications and morbidities, to the best of the authors' knowledge, SIADH has not been reported among patients with tyrosinaemia type 1. Although hyponatraemia was reported in a patient with tyrosinaemia in the past, sufficient data to ascertain whether this was attributed to SIADH was not provided or explicitly discussed. More recent reviews and clinical guidelines about tyrosinaemia also do not mention or consider SIADH as part of complications of this condition. ${ }^{1,2}$ However, it is of interest to note that tyrosinaemia type 1 has been considered in the diagnostic work-up of an adult patient who presented with SIADH for the first time in adulthood. ${ }^{6}$

The current patient presented with severe symptomatic hyponatraemia and developed seizures as a complication. This indicates that it could be a potentially serious complication in any patient with tyrosinaemia admitted with acute crisis complicating non-adherence to therapy. Hyponatraemia secondary to SIADH in this patient was diagnosed based on the following criteria: ${ }^{4}$ (1) hypo-osmolality; (2) inappropriately concentrated urine (>100 mOsm/ $\mathrm{kg} \mathrm{H}_{2} \mathrm{O}$, although usually higher than serum); (3) natriuresis $>30 \mathrm{mEq} / \mathrm{L}$ (depending on sodium intake); (4) reversal of renal sodium wasting and correction of hyponatraemia after water restriction; and (5) normal renal, adrenal, thyroid, cardiac and liver functions and no signs of volume depletion (e.g. absence of diuretic intake).

The current patient met the diagnostic criteria of SIADH; she was euvolaemic with the hyponatraemia being associated with low osmolality in combination with inappropriately concentrated urine $(284 \mathrm{mOsmol} /$ $\mathrm{kg}$ ) and natriuresis (urine $\mathrm{Na}^{+}>101 \mathrm{mmol} / \mathrm{L}$ ). The renal function, thyroid function and cortisol were all within the normal range. This diagnosis was also supported by clinically improved sodium concentration after water restriction following failure of improvement with hypertonic saline (3\%) boluses [Table 1].

In retrospect, SIADH was likely to have complicated the acute porphyria crisis. However, the authors speculate whether recurrent SIADH could also be a neurological complication of poorly controlled tyrosinaemia type 1 . If SIADH is truly an 
under-recognised or under-reported complication in patients with tyrosinaemia type 1 , it may have significant therapeutic implications for such patients admitted with acute porphyria crisis.

The management of these crises would typically include increased dextrose concentration delivered in dextrose water solutions at a level more than maintenance need. However, this practice may worsen hyponatremia due to SIADH, even in the presence of normal saline added to the solution. In this regard, care should be taken when making a decision on the choice and rate of intravenous fluid administration. This is specifically true when hyponatraemia or borderline low sodium is encountered in patients with tyrosinaemia type 1 presenting with acute porphyria crisis. This would also need to be reflected in future revisions of practice guidelines.

\section{Conclusion}

The authors report SIADH in a patient with uncontrolled tyrosinaemia type 1 . It is proposed that this diagnosis should be taken into consideration when making a decision regarding fluid management of patients admitted with acute crisis.

\section{References}

1. Chinsky JM, Singh R, Ficicioglu C, Van Karnebeek CD, Grompe M, Mitchell G, et al. Diagnosis and treatment of tyrosinemia type I: A US and Canadian consensus group review and recommendations. Genet Med 2017; 19. https://doi.org/10.1038/gim.2017.101.

2. De Laet C, Dionisi-Vici C, Leonard JV, McKiernan P, Mitchell G, Monti L, et al. Recommendations for the management of tyrosinaemia type 1 . Orphanet J Rare Dis 2013; 8:1-9. https://doi. org/10.1186/1750-1172-8-8.
3. Sassa S, Kappas A. Hereditary tyrosinemia and the heme biosynthetic pathway. Profound inhibition of $\delta$-aminolevulinic acid dehydratase activity by succinylacetone. J Clin Invest 1983; 71:625-34. https://doi.org/10.1172/JCI110809.

4. Yasir M, Mechanic OJ. Syndrome of Inappropriate Antidiuretic Hormone Secretion. [Updated 2021 Mar 21]. In: StatPearls [Internet]. Treasure Island, USA: StatPearls Publishing, 2021.

5. Decaux G, Musch W. Clinical laboratory evaluation of the syndrome of inappropriate secretion of antidiuretic hormone. Clin J Am Soc Nephrol 2008; 3:1175-84. https://doi.org/10.22 15/CJN.04431007.

6. Bartter FC, Schwartz WB. The syndrome of inappropriate secretion of antidiuretic hormone. Am J Med 1967; 42:790-806. https://doi.org/10.1016/0002-9343(67)90096-4.

7. Nabin A, Thapa LJ, Paudel R, Rana PV. Acute intermittent porphyria with SIADH and fluctuating dysautonomia. Kathmandu Univ Med J 2012; 10:96-9. https://doi.org/10.3126/kumj.v10i2.7354.

8. Muraoka A, Suehiro I, Fujii M, Murakami K. delta-Aminolevulinic acid dehydratase deficiency porphyria (ADP) with syndrome of inappropriate secretion of antidiuretic hormone (SIADH) in a 69-year-old woman. Kobe J Med Sci 1995; 41:23-31.

9. Yazıcı H, Canda E, Er E, Kılınç MA, Uçar SK, Karapınar B, et al. Tyrosinemia type I and reversible neurogenic crisis after a onemonth interruption of nitisinone. J Pediatr Res 2018; 5:57-9. https://doi.org/10.4274/jpr42275.

10. Suarez JI, Cohen ML, Larkin J, Kernich CA, Hricik DE, Daroff RB. Acute intermittent porphyria. Clinicopathologic correlation: Report of a case and review of the literature. Neurol 1997; 48:1678-84. https://doi.org/10.1212/WNL.48.6.1678.

11. Bloomer JR, Berk PD, Bonkowsky HL, Stein JA, Berlin NI, Tschudy DP. Blood volume and bilirubin production in acute intermittent porphyria. N Engl J Med 1971; 284:17-20. https:// doi.org/10.1056/NEJM197101072840104.

12. Yonatan Edel, Rivka Mamet. Porphyria: What Is It and Who Should Be Evaluated? Rambam Maimonides Med J 2018; 9:e0013. https://doi.org/10.5041/RMMJ.10333.

13. AndersonKE,BloomerJR,BonkovskyHL,KushnerJP,PierachCA, Pimstone NR, et al. Recommendations for the diagnosis and treatment of the acute porphyrias. Ann Intern Med 2005; 142:439-50. https://doi.org/10.7326/0003-4819-142-6-20050315000010 